Developing Reading Materials In Narrative Texts For Second Grade Students Of Fashion Design Department At SMK Negeri 8 Medan

\author{
AN ARTICLE
}

Submitted in Partial Fulfillment of the Requirements for the Degree of Sarjana Pendidikan

By:

IRDA SILVIA SITEPU

Registration Number: 2133321023

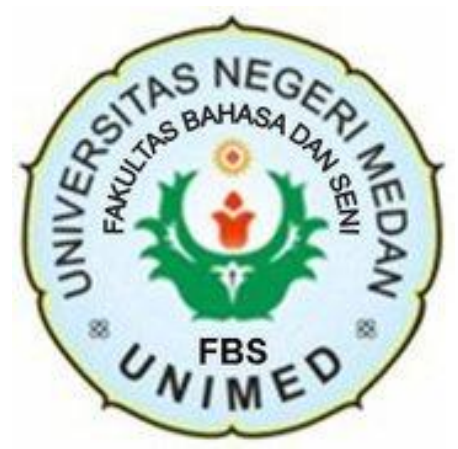

ENGLISH AND LITERATURE DEPARTMENT

FACULTY OF LANGUAGES AND ARTS

MEDAN STATE UNIVERSITY

2018 
ARTIKEL

Developing Reading Materials In Narrative Texts For Second Grade Students

\section{Of Fashion Design Department At SMK Negeri 8 Medan}

Disusun dan Diajukan oleh:

Irda Silvia Sitepu

Registration Number : 2133321023

\section{Telah diverifikasi dan dinyatakan memenuhi syarat untuk diunggah pada jurnal online}

\section{Medan, Maret 2018}

Menyetujui

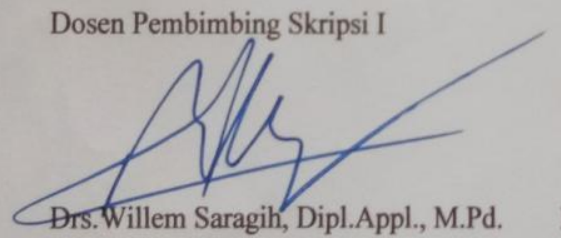

NIP. 195812311986011011
Dosen Pembimbing Skripsi II

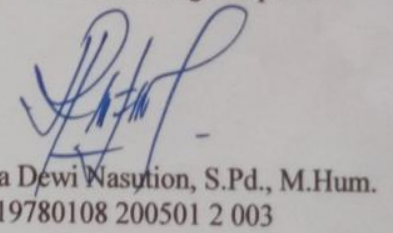

Ka. Program Studi

Pendidikan Bahasa Inggris

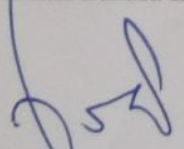

Nora Ronita Dewil S.Pd., S.S., M.Hum.

NIP. 198005222008122003 


\title{
Developing Reading Materials In Narrative Texts For Second Grade Students Of Fashion Design Department At SMK Negeri 8 Medan
}

\author{
* Irda Silvia Sitepu \\ ** Drs.Willem Saragih \\ ** Rafika Dewi Nasution
}

\begin{abstract}
This study aims to develop reading materials needed for students at SMKN 8 Medan.The research was conducted by Research and Development (R \& D) develop through six phases; gathering information and data, analyzing data, develop new materials, validating by experts, revising and final product. It was conducted at SMKN 8 Medan, especially grade XI. The data were gathered by administering interview to English teacher and distributing questionnaire to 27 students' needs. The interview and questionnaire results prove that the students need English reading materials which contain the appropriate knowledge or topic with the Kemendikbud (Kementerian Pendidikan dan Kebudayaan), syllabus and students' need. Thus, developing materials are narrative text, the narrative texts expose the texts about fashion which are adjacent with students' need. The products have been validated by experts. The average scores are 4.6 or $92 \%$ from English Lecturer and 4.75 or $95 \%$ or from English Teacher. It means the developing materials categorized as relevant or appropriate for students at SMN 8 Medan grade XI
\end{abstract}

Keywords: Research and Development $(R \& D)$, Reading Materials, Vocational School, Fashion Design Program

\footnotetext{
*Graduate

** Lecturer
} 


\section{INTRODUCTION}

\section{Background of the Study}

In Indonesia, English is the first foreign language. It is used in English classrooms but not in everyday communication. This condition makes English difficult for Indonesian students, Hamra and Syatriana (2010). Not only that, In Indonesia also most schools are still using the textbooks as their main source of learning, students were studied by their textbook only. In a truth, not all of the students are really interested to read it. In this phenomenon can be caused the unsuitable the learners' reading materials textbook and learners' need.

Based on Herlina (2012) teachers need to find materials which suits on the curriculum, that is based on the standard competence and the basic competence

Teachers of English need other texts/material for very clear reasons. Simplified readers are really designed to motivate learners to read more and thus become familiar with written English to improve reading fluency. The reading texts in low-level in their textbook, if there are any, are usually intended for language input and not for the development of reading abilities. This means that they are very often at a level below reading ability of the learners. In addition, these texts may not be relevant or appropriate for particular learners. 
Based on School-based Curriculum, the English materials for vocational high school should include the four skills: listening, reading, speaking and writing. According to psycholinguistics, human's mind have two categories in teaching learning process. The first category is concern to human's ability in comprehend the language. Human can comprehend the language by their ability in listening and reading activity. The second category is about human's ability while producing the language. Human can produce the language from word until the sentences by their speaking and writing's skills. Based on these reasons, the students do not understand the lesson from hearing the teacher's explanation only but also from reading their materials.

The students use the material as their source in teaching-learning process, especially in reading subject. The students need a good material to help them to understand the subject during the teaching learning process. The material should have a correlation with their need and necessity. The authentic materials; the English should be specialized, support their vocation, and relevant with the purpose of their vocation.

According to Curriculum 2013, English in vocational high school now is categorized as a compulsory subject. It means that vocational high school students must learn it and achieve the basic competences that have been listed according to the curriculum. The aim of the English teaching is to form students $^{6}$ language skills. Spoken and written languages are the basis of the learning language which means that the students have to master both of them. 
Reading is the practice of using text to create meaning. Due to this idea, the students of vocational high school must learn some texts which refer to the use of language in real life situations. To reach the aim of teaching English, especially for reading, English in vocational high schools now use core competence and basic competence (CC-BC) to measure the students' achievement.

Based on Syllabus, the available text book there are two basic curriculum about narrative text, especially in narrative recount text, they are 3.11 and 4.15 . In 3.11 basic competence, narrative recount text should analyze the social function, structure of the text and lexicogrammatical from short public figure biography which is appropriate with the context. In 4.15 basic competence, the students can comprehend the meaning from the short public figure biography.

In fact, this research found the teaching materials were not appropriate with their vocation. The students who take a vocation of fashion design were taught by using the teaching materials which are unsuitable with their majority in fashion design. Some topics in the textbook are "Life and Times of Ki Hajar Dewantara" and "The Last Leaf". These text shows that these materials are not appropriate with fashion design students' need.

The students need a material which can help them to understand the subject easier. The material should make the students will interest read it during the teaching learning process. The topic should make the students easier to 
catch the subject, exactly appropriate with their vocation, such as "The Biography of Ivan Gunawan", and "The Biography of Dian Pelangi" as a proffesional designer in Indonesia. They still use the general topic in english reading material

From the reasons above, the researcher applied the ESP (English For Specific Purpose) in SMK N 8 Medan. ESP helped the researcher to develop the reading materials with suitable form for student's need and necessity. ESP was an approach to make a good material which appropriate with student's need.

Based on the background above, this research focused on developing reading material by using ESP form which had been applied in SMK N 8 Medan.

\section{REVIEW OF RELATED LITERATURE}

According to Burns, Roe and Ross (1984), reading is a complex act that must be learned. It is also a means by which further learning takes place. In other words, a person learns to read and reads to learn.

Based on Klingner (2007:2) reading comprehension is the process of constructing meaning by coordinating a number of complex process that included word reading, word and world knowledge, and fluency. It refers to the ability in interpreting the words, to understand the meaning and the relationships between the ideas conveyed in the text. 
Developing these materials are using an ESP approach. ESP is not a particular kind of language or methodology, nor does it consist of a particular type of teaching material. Understood properly, it is an approach to language learning, which is based on learner need.

The foundation of all ESP is the simple question "Why does this learner need to learn foreign language', From this question will flow a whole host of further questions, some of which will relate to the learners will need to operate, some to the given learning context. But this whole analysis drives from an initial identified need on the part of the learner to learn a language. ESP, then, is an approach to teaching language in which all decisions as to content and method are based on the learner's reason for learning.

\section{RESEARCH METHODOLOGY}

This research using development research which was adapted from Borg and Gall (1983) in fulfilling the students' need in reading comprehension material.

Borg and Gall (1983:775) there were 10 stages in model of developing, there were: research and information collecting, planning, develop preliminary form of product, preliminary field testing, main product revision, main field testing, operational product revision, operational field testing, final product revision, and dissemination and implementation. The research had been

conducted by using developmental research in fulfilling the students' need in 
reading comprehension material. But this research used 6 stages because of the factor of time, effectiveness and cost limited. They were :

1. Research and Information Collecting

2. Planning/Analyzing

3. Developing

4. Operational Product Revision/Validation

5. Operational Field Testing/Revision

6. Final Product

The instrument of data collection was taken from Interview, Questionnaires and Documents.. Documents such as syllabus, lesson plan and textbook had functions as the tools to collect data. Interview had been collected from English teacher to find information about the students' reading proficiency, students' difficulties in reading and information of the existing reading materials. Questionnaires had been collected from 27 students in SMK 8 Medan in Fashion Design Program. It could help the researcher to collect their problem study with their existing materials and their needs'.

The Data was collected in the form of qualitative. The qualitative data was obtained from the questionnaires of the students and the interview of teacher. 


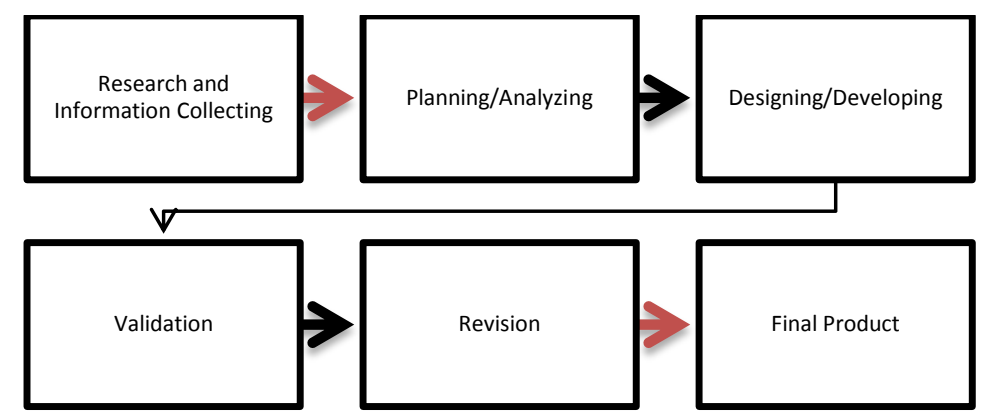

Figure 3.1 Research and Development cycle by Borg and Gall (1983).

\section{RESEARCH FINDINGS AND DISCUSSION}

Research and Collecting the information have been done. It was supposed to get the problem of the study. From the information that has been done, there were two problems. First, the reading materials in their English book were not suitable for their learning needs'. Second, there should be materials development which fulfilled their needs' to improve their motivation to learn English.

There were 27 students of grade XI of SMKN 8 Medan, concerned on Fashion Design Department which answered the questionnaires and Interview session had been given to English teacher.

Need analysis should be maintained that any course should be based on an analysis of learner needs'. These analyzing the data come from need analysis. Need analysis were useful to develop the materials which suitable with students' need, there were : target needs and learning needs. 
Target needs analysis was done to know an umbrella term in learning English; necessities; lack; wants of the students. The data were collected from questionnaire which distributed to 27 students, and the information which has found on interview session for their English teacher.

Learning needs analysis was done to know how students learn to do what they do with language, the exit roads within the student's mind (knowledge, skills and strategies) and their motivation. From the questionnaires and interview were known that students able follow the learning process in the class which given by their teacher. Their knowledge and the topic of the narrative text were not relevant. Not only that, their vocabulary in reading also low and hard to match it with the general topic of their text. It made they was not interest to read their text.

After the data had been collected, then the developing materials process started from changed the previous theme of reading text. The previous texts were about Biography of Ki Hajar Dewantara and The Last Leaf. These texts had general knowledge but they did not match to students' need as Fashion Design Department.

It changed to be fives texts, they are : Biography of Fatmawati, Biography of Ivan Gunawan, Biography of Dian Pelangi, Biography of Barli Asmara, and Biography of Anne Avanti. 
The materials of narrative recount "biography". It were; introduction, important event in chronological order and interpretation and closing remarks.

The next step was expert judgment process. The validating of materials development was evaluated by two experts, English Teacher and English Lecturer. It was determining about the materials which has been appropriate or not. The final product has been validated by the expert, Prof. Dr. Amin Saragih. MA, as a English Lecturer and Nurlina Sebayang S.Pd as a English Teacher. As the result from the first validator evaluation $92 \%$ and it was categorized as relevant. Beside that from the second validator evaluation also got $95 \%$ and it was categorized as relevant.

Thus, the final draft or the developed English reading materials were valid and appropriate to be used as learning materials for second grade students in Fashion Design Department of SMK Negeri 8 Medan.

\section{CONCLUSION AND SUGGESTION}

\section{The Conclusion}

After analyzing the data, the conclusion are collected as follows :

1. The students of SMK N 8 Medan, especially for Fashion Design Department needed the English reading materials which could support their target and learning needs. Their target needs useful to support their 
knowledge about the Fashion Design and their learning needs also useful for preparing their skill to get a job which suitable with their majority now. They will be easier to understand the materials which appropriate with their needs'.

2. The reading materials on general English book did not match to their needs' and it should be developed. The English materials should be developed by using 6 stages, they were ; Research and Information Collecting, Analyzing the data, Developing materials, Validating the new materials by the experts, Revising materials based on experts' suggestions and Revised developing reading materials or Final Product.

\section{A. Suggestions}

In relation to the conclusion, the suggestions are as follows :

\section{Teacher}

Teachers should consider the students' need to choose the suitable learning materials for her/his students. The learning process can be successful if the reading materials were appropriate with their students' majority. The teacher should use an authentic learning materials based on the specific vocation which is had by their students. The teacher also needs to develop the existing materials if they found it was too general for their students of SMK N 
8 Medan, especially Fashion Design Department which had the specific needs.

\section{Institution}

The institution should selective to choose the materials which will be distributed in their school. The institution should find the books which match with their students' need and their mission in the school. It can help them to get the best students and result in the end. The institution should prepare the appropriate materials which can help the teacher easier to teach the students in the class and it useful for the students easier to get what they have had.

\section{Other Researcher}

The other researcher can support in developing reading materials especially in narrative text for vocational school with using more authentic questionnaire to get an authentic data also. 


\section{REFERENCES}

Borg,W.R.,Gall,J.P.,Gall,M.D. (1983). Educational Research : An Introduction $\left(7^{\text {th }} e d\right)$.Boston : Pearson Education,Inc.

Burns.,Roe.,Ross. (1984). Teaching Reading in Today's Elementary Schools $\left(3^{\text {rd }}\right.$ ed). Boston : Houghton Mifflin Company.

Hamra,A.,\& Syatriana,E. (2010). Developing A Model of Teaching Reading Comprehension for EFL Students. TEFLIN Journal, Vol 21(1),1-3.

Herlina. (2012). Developing Reading Narrative Text Materials for Eighth Grades of Junior High School Implemented with Character Building. English Educational Journal, 2(2),2.

Kemendikbud. (2014). Bahasa Inggris. Jakarta : Kementerian Pendidikan Dan Kebudayaan Republik Indonesia.

Klingner,J.K.Vanghn, S.,\& Boardman, A.(2007). Teaching Reading Comprehension to Students with Learning Difficulties. New York, NY : Guilford. 